\title{
A RANDOMIZED TRIAL - INTENSIVE TREATMENT BASED IN IVERMECTIN AND IOTA-CARRAGEENAN AS PRE-EXPOSURE PROPHYLAXIS FOR COVID- 19 IN HEALTHCARE AGENTS
}

\section{*Corresponding author:}

40 Maria Peral de Bruno, MSc., Ph.D.

41 Health Research Institute, Ministry of Health.

42 Virgen de la Merced 196.

43 (4000) San Miguel de Tucumán, Tucumán, Argentina.

44 E-mail: mperal0150@gmail.com

44
45 E-mail: mperal0150@gm

Chahla, Rossana Elena

Medina Ruiz, Luis

Ortega, Eugenia Silvana

Health Research Institute, Ministry of Health, SI.PRO.SA, Tucumán, Argentina.

Morales, Marcelo Fabio

Clinical Hospital “Angel C. Padilla”, Tucumán, Argentina.

Barreiro, Francisco

Medical Center Emergence, Tucumán, Argentina.

George, Alexia

Medical Center Emergence, Tucumán, Argentina.

Mancilla, Cesar

D’ Amato, Sylvia Paola

Barrenechea, Guillermo

Goroso, Daniel Gustavo

Research and Technology Center, Mogi das Cruzes University, Brazil.

Peral de Bruno, Maria de los Angeles*

Health Research Institute, Ministry of Health, SI.PRO.SA, Tucumán, Argentina.

Word count: 3274 
medRxiv preprint doi: https://doi.org/10.1101/2021.03.26.21254398; this version posted March 30, 2021. The copyright holder for this preprint (which was not certified by peer review) is the author/funder, who has granted medRxiv a license to display the preprint in perpetuity.

It is made available under a CC-BY-NC-ND 4.0 International license .

\section{$46 \quad$ Key Point}

47

48

49

50

51

52

IMPORTANCE: The emergency of COVID-19 requires the implementation of urgent strategies to prevent the spread of the disease, mainly in health personnel, who are the most exposed and has the highest risk of becoming infected with the SARS-COV-2. Drug repurposing is a pragmatic strategy, a faster and cheaper option, compared to the new drug development that has proven successful for many drugs and can be a key tool in emergency situations such as the current one that requires quick action. In addition, considering the limited access to vaccines for developing countries, preventive use of ivermectin can be a palliative that minimizes the risks of infection.

OBJECTIVE: To evaluate the protective effect of the combination Ivermectin / IotaCarrageenan (IVER/IOTACRC), intensive treatment with repeated administration in oral- and nasal-spray, respectively, as a prophylaxis treatment prior to exposure to SARS-CoV-2, in health personnel at Public Healthcare Centers.

PARTICIPANTS, DESIGN AND SETTING: Randomized controlled 1-1 clinical trial in Personal Health, $\mathrm{n}=234$. The subjects were divided into experimental (EG: $\mathrm{n}=117 ; 39.6 \pm 9.4$ years old, $65 \mathrm{~F})$ and control groups $(\mathrm{CG}: \mathrm{n}=117 ; 38.4 \pm 7.4$ years old, $61 \mathrm{~F})$. The EG received Ivermectin orally 2 tablets of $6 \mathrm{mg}=12 \mathrm{mg}$ every 7 days, and Iota-Carrageenan 6 sprays per day for 4 weeks. All participants were evaluated by physical examination COVID-19 diagnosed with negative RT-PCR at the beginning, final, and follow-up of the protocol. Differences between the variables were determined using the Chi-square test. The proportion test almost contagious subject and the contagion risk (Odds Ratio) were calculated using software STATA. The level of statistical significance was reached when $\mathrm{p}$-Value $<0.05$.

RESULT: The number of subjects who were diagnosed with COVID-19 in EG was lower, only 4 of $117(3.4 \%)$ than subjects in CG: 25 of $117(21.4 \%)\left(P\right.$-Value $\left.=1.10^{-5}\right)$.

75 Nineteen patients had mild symptoms, 4 were in EG whereas, 15 were in CG ( $p$-Value $76=0.001)$. Seven subjects were moderate, and 3 with severe diagnostics, all them in CG. 77 The probability (Odds Ratio) of becoming ill with COVID-19 was significantly lower 
78 in EG with values of $0.13,95 \% 0.03$ to $0.40 ; p$-Value $=1.10^{-4}$, this value $(<1)$ indicates

79 a protective effect of the IVER/IOTACRC in the EG. Logistic regression test 80 demonstrated that treatment was effective to prevent COVID-19 (Odds Ratio 0.11, $8195 \% 0.03$ to $0.33 ; p$-Value $\left.=1.10^{-4}\right)$. We also found that when increase the age, 82 decrease contagious risk (Odds Ratio 0, 93, 95\% 0.88 to $0.98, p$-Value $=0,02$ ). On the 83 other hand, the probability of contracting COVID-19 was dependent on the patient's 84 preexisting comorbidity (Odds Ratio $5.58,95 \% 2.20$ to $14.16, p$-Value $=1.10^{-5}$ ). The 85 other variables sex and designation were independent.

87 CONCLUSION: The intensive preventive treatment (short-term) with 88 IVER/IOTACRC was able to reduce the number of health workers infected with 89 COVID-19. This treatment had also effect in preventing the severity of the disease, 90 since all patients treated were mild. We propose a new therapeutic alternative for 91 prevention and short-term intervention scheme (intensive) that is of benefit of the 92 health worker in this pandemic accelerated time. This intervention did not produce 93 lack of adherence to treatment or adverse effects.

95 Trial Registration: ClinicalTrials.gov Identifier: NCT04701710 
medRxiv preprint doi: https://doi.org/10.1101/2021.03.26.21254398; this version posted March 30, 2021. The copyright holder for this preprint (which was not certified by peer review) is the author/funder, who has granted medRxiv a license to display the preprint in perpetuity.

It is made available under a CC-BY-NC-ND 4.0 International license .

\section{Background}

At the end of December 2019, the incidence of atypical pneumonia of unknown

101 cause was reported in the Chinese city of Wuhan ${ }^{1}$. Since then, the cases have spread on

a global scale generating the new COVID-19 pandemic, which represents the largest global public health crisis of this generation ${ }^{2}$. Genetic studies identified a new coronavirus, which was named SARS-CoV-2 due to its structural similarity with others

SARS-related coronaviruses ${ }^{3}$.

Considering that there are no specific therapies approved by the United States

107 Food and Drug Administration (FDA) for severe acute respiratory syndrome (SARS-

$108 \mathrm{CoV}-2)^{4}$, the repositioning of different drugs with established safety profiles on the

109 market is being studied in clinical trials and compassionate use protocols based on in

110 vitro activity (against SARS-CoV-2 or related viruses) and / or on the limited clinical

111 experience available. Drug repurposing is a pragmatic strategy, a faster and cheaper

112 option, compared to the new drugs development that has proven successful for many

113 drugs and can be a key tool in emergency situations such as the current one that requires

114 quick action ${ }^{5-7}$. In addition, considering the limited access to vaccines for developing

115 countries, preventive use of ivermectin can be a palliative that minimizes the risks of

116 infection in the population.

117 Ivermectin is a broad spectrum anti parasitic agent approved by the FDA that in

118 last few years has shown to have in vitro antiviral activity against a wide range of

119 viruses ${ }^{4,8-11}$. Caly et al. (2020) suggested that ivermectin's nuclear transport inhibitory

120 activity may be effective against SARS-CoV-2 ${ }^{12}$. Different studies indicate that

121 ivermectin would have two mechanisms of action on the COVID 19 virus: extra and 122 intracellular. The first is through interaction with ionophores cavities or channels 123 present in the cell membrane that electrically trap the corona of the virus capsid and 
124 prevent access to the cell ${ }^{13}$. The second is carried out by destabilization of the importin

125 heterodimer complex (IMP $\alpha / \beta 1)^{13}$. When destabilized, the entry to the nucleus of the

126 virus proteins is blocked, preventing viral replication. This fact will probably result in a

127 reduction of the antiviral responses inhibition, leading to a normal and more efficient

128 antiviral response.

129 In line with these studies, numerous clinical trials are evaluating the potential of

130 ivermectin against COVID-19 with results that are not conclusive yet regarding its

131 efficacy and safety. At the end of March 2021, there were about 60 studies registered in

132 https://www.clinicaltrials.gov and 43 studies listened https://www.who.int/clinical-

133 trials-registry-platform about the safety and effectiveness of Ivermectin in COVID-19

134 patients, for treatment and prophylaxis ${ }^{14}$. A preliminary meta-analysis realized with 18

135 randomized Clinical Trials in 2282 patients, showed a faster time to clinical recovery

136 and signs of viral clearance in patients who took ivermectin, comparating with control 137 group $^{15}$.

138 Carrageenans, are polysaccharides produced by algae of various families of the

139 Rhodophyceae (red algae), its use as a food thickener additive is approved by the FDA.

140 Its antiviral activity has been attributed to its ability to interfere with the binding of

141 virions to host cell. Carrageenans are in vitro inhibitors of several viruses, including

142 herpes simplex virus, Japanese encephalitis virus, human papilloma virus, varicella

143 zoster virus, human rhinoviruses, and others ${ }^{16}$.

144 In this context, Health personnel are at high risk of developing the disease. Their

145 contact with infected patients puts them at greater risk from high viral loads, resulting in

146 more serious and prolonged illness ${ }^{17-20}$. Treatment with oral ivermectin, associated with

147 iota-Carrageenan (antiviral association) applied locally in the nasal and oral cavity,

148 would decrease the probability of the appearance or progress of clinical manifestations 
149 and the appearance of severe disease, and would decrease the viral load in the upper

150 airway and the time of virus shedding ${ }^{13}$.

151

\section{Objective}

153 The purpose of this study was to assess the effect of oral Ivermectin treatment,

154 which has been associated with iota-carrageenan in repeated doses through the nasal and

155 oral topical route, on the appearance and eventual progression of COVID-19 disease in

156 a healthy population that are exposed to it and have a higher risk of contagion of SARS-

157 COV-2 for being health personnel from community health centers, compared to

158 standard care (usual practice).

Primary Outcome

162 Reduction the infections rate for COVID-19 disease in healthcare agents.

163

164 Secondary Outcomes

165 Reduction in symptoms number's presence, and protection against the appearance of

166 severe stages for COVID-19 disease.

168 Material and Methods

169 Sample Size

170 Sample size was determined by the test comparing two proportions ${ }^{21}$. It were

171 considerate the following parameters to bilateral test: $95 \%$ confidence level, $95 \%$ 
medRxiv preprint doi: https://doi.org/10.1101/2021.03.26.21254398; this version posted March 30, 2021. The copyright holder for this preprint (which was not certified by peer review) is the author/funder, who has granted medRxiv a license to display the preprint in perpetuity.

It is made available under a CC-BY-NC-ND 4.0 International license .

172 statistical power, $95 \%$ proportion of infected patients in the CG, 85\% proportion of

173 infected patients in the EG. The sample size calculated, without considering losses, was

174231 participants. Sample size adjusted to $20 \%$ loss ratio was 289 participants.

175

176 Participants

177 The total group $\mathrm{n}=300$ to enroll included personnel who perform patient care 178 and administrative tasks identified like: i) Healthcare: medical personnel, nurses, 179 kinesiologists; and ii) No Healthcare: administrative and cleaning personnel. Health 180 personnel belonging to the Tucumán State Health System (SI.PRO.SA, Tucumán, 181 Argentina) participated in the study from October 2020 to December 2020. The 182 recruitment procedure was managed by coordinators from each health care center who 183 accept to participate in this trial. Enrollment was staggered until complete the sample 184 size. The people who agreed to participate in the study gave their informed consent 185 before starting the study (Research Ethics Committee / Health Research Directorate, file 186 number 52/2020). The clinical trials registry number is NCT04701710. This study 187 conforms to all CONSORT guidelines and re-ports the required information accordingly 188 (see Supplementary Checklist).

Inclusion criteria

191 Participants over 18 years of age, of both sexes, and at the start of enrollment, no

192 subject had Covid-19 disease diagnosed by negative RT-PCR. The exclusion criteria 193 were people under 18 years of age, pregnant or actively breastfeeding women, 194 presenting symptoms related to COVID-19 disease, concurrent autoimmune or chronic 195 disease, immune suppression, active infectious diseases, a history of previous SARS196 CoV-2 infection confirmed by RT-PCR, medical history, and a clinical questioning. 
Design

199 Randomized controlled clinical trial (1:1). Once the sample was consolidated, each

200 patient was assigned an ID corresponding to a number from 1 to 234 . The selection to

201 each group was performed through a random number generation process by an Excel

202 spreadsheet. Then, 117 of them were randomly selected to generate the CG and EG.

203 Figure 1 shown the consort flow diagram.

\section{Intervention Protocol}

210 The individuals of the EG received active treatment with IVER/IOTACRC. Ivermectin

211 was administered orally in 2 tablets of $6 \mathrm{mg}=12 \mathrm{mg}$ every 7 days and Iota-Carrageenan

2126 sprays per day. The entire treatment lasted 4 weeks. The CG did not receive any

213 prophylactic treatment. Both groups used standard biosecurity care and personal

214 protective equipment (PPE).

215 A post-control follow-up was carried out at 14 days (remote clinical telemedicine

216 follow-up) at the end of which an RT-PCR test was performed. EG and CG patients

217 were evaluated every 7 days in 4 visits from the beginning of the study. Enrolled

218 subjects completed symptom questionnaires (including reporting any adverse effects of

219 treatment), physical examinations, and COVID-19 nasopharyngeal secretion tests (RT-

220 PCR) at each time. Also in the visit, in person, was supplied the corresponding dose for

221 the week. Cases will be classified according to the WHO definitions of COVID-19 
222 cases $^{22}$

224 Security definitions

225 Adverse Event (AE) was defined as any medical event, signs, symptoms, or disease

226 temporarily associated with the use of the medication, which could occur in the subjects 227 enrolled in the study ${ }^{23}$.

Adherence to treatment

230 The World Health Organization (WHO) defines adherence to treatment as compliance

231 with it; that is, taking the medication according to the dosage of the prescribed schedule;

232 and persistence, taking the medication over time ${ }^{24}$. We quantify adherence to treatment

233 through weekly controls that include drug administration and a clinical questioning

234 which includes the report of adverse events. Adhesion tests like Hermes, Morisky and

235 Green have not been used, since they have been designed for treatment of chronic

236 diseases with daily drug intake ${ }^{25}$. Coordinators in charge of each health care center were

237 responsible for the recruitment and accompaniment during the trial.

239 Statistics

240 Categorical variables were analyzed with frequencies and percentages, and continuous

241 variables with mean and standard deviation (SD). Pearson's Chi-square and proportions

242 test, as appropriate, were used to analyze the statistical differences between the

243 qualitative variables of each group. To know the contagion risk, the Odds Ratio (OR)

244 was calculated. A Logistic Regression analysis was carried out to know the dependence

245 between the study variables. A value of $\mathrm{p}<0.05$ was considered significant.

246 Calculations were performed using STATA 11.2. 


\section{Results}

\section{Demographic profile}

250 In total, 234 individuals from the health personnel were recruited for this study; 117

251 received treatment with IVER/IOTACRC and 117 within the control group who used

252 biosecurity measures. All the participants completed the study. $57.26 \%$ of the

253 participants enrolled in total group were women. The median age in total group was 38

254 years (min: 22; max: 69). 77.4\% of the study participants were healthcare personnel.

255 Table 1 shows the demographic profile and descriptions of comorbidities for the 256 experimental and control group.

Table 1. Demographic profile.

261 Table 1 shows that the demographic profile and the reported comorbidities distribution

262 of the recruited population is homogeneous, $p$-Value> 0.05 , in all the fields initially

263 analyzed. Only, it was observed that the obese population is greater in the CG than in

264 the EG, a relationship 18 vs. 10 , respectively, with $p$-Value $=0.06$ at the borderline.

265 Similarly, the distribution of health agents in relation to their function was different in

266 each group, after randomization was performed ( $p$-Value <0.05). It should be noted that

267 initially, no subjects had compatible COVID-19 signs, and all were diagnosed with 268 negative RT-PCR. 
medRxiv preprint doi: https://doi.org/10.1101/2021.03.26.21254398; this version posted March 30, 2021. The copyright holder for this preprint (which was not certified by peer review) is the author/funder, who has granted medRxiv a license to display the preprint in perpetuity.

It is made available under a CC-BY-NC-ND 4.0 International license .

270

271

272

273

274

275

276

277

278

279

280

281

282

283

284

285

286

287

288

289

290

291

292

293

294

295

Clinical report and COVID-19 case in EG vs. CG

Table 2 shows the clinical report of the health agents after being recruited in the research. All health professionals and non-professionals were exposed to contracting COVID-19 for work reasons typical of the service.

$<$ Table $2>$

Table 2. Clinical report. $\left({ }^{*}\right) p$-Value $<0.05$.

COVID-19, were reported in the CG (p-Value <0.05). The most frequent symptoms were fever (21), taste and / or smell disturbance (19), and headache (19). With intermediate frequency of symptoms, cases with polymyoarthralgia (9), diarrhea (9), abdominal pain (8), and low oxygen saturation $\left(\mathrm{SpO}_{2}\right)$ (6) were reported. Symptoms related to ALRI symptoms and signs (1) were reported with lower frequencies. Table 2 shows the significant differences $(p$-Value $<0.05)$ between EG vs CG in relation to each of the reported symptoms. CG had a prevalence of all the most frequent symptoms in people who acquired COVID-19.

\section{$<$ Figure 2>}

Figure 2. COVID-19 case in EG vs. CG. A) Number of COVID-19 and healthy cases in Experimental and Control Group (n=234). B) Clinical state of the COVID-19 cases in Experimental and Control Group $(n=234)$. 
medRxiv preprint doi: https://doi.org/10.1101/2021.03.26.21254398; this version posted March 30, 2021. The copyright holder for this preprint (which was not certified by peer review) is the author/funder, who has granted medRxiv a license to display the preprint in perpetuity.

It is made available under a CC-BY-NC-ND 4.0 International license .

29619 in EG was lower, only 4 of 117 (3.4\%), than subjects in CG: 25 of $117(21.4 \%)$ (p-

297 Value $=1.10^{-4}$ ). Patients diagnosed with COVID-19 were classified as mild, moderate

298 and severe, according to the gravity cases. Figure 2B shows the distribution of cases in

299 each group and their respective classification.

300 Nineteen patients had mild classification for COVID-19, $n=4$ in EG, and $n=15$

301 in CG $(p$-Value $=0.001)$. Seven subjects were moderate, and 3 with severe diagnostics,

302 all them were in CG. In addition, it was found that in the EG people who contracted

303 COVID-19 only $1 / 4$ had any symptoms, while the CG 24/25 ( $p$-Value $\left.=1.10^{-5}\right)$.

304

305

Odds Ratio and variables influence on intervention

306

307

lower in EG with values of $0.13,95 \% 0.03$ to $0.40 ; p$-Value $=1.10^{-4}$, than in GC with

values of $7.67,95 \% 2.57$ to $22.85 ; p$-Value $=1.10^{-4}$. The value $<1$ indicates a protective

effect of the IVER / IOTACRC for EG. Consequently, people with treatment decrease

their chance of contracting COVID-19 by $87 \%$.

311 Logistic regression test was also performed in order to determinate the influence

312 of different variables on the clinical trials. In this model dichotomous dependent

313 variable was used as having or not suffering from COVID-19 in relation to the five

314 variables: IVER/IOTACRC intervention, comorbidity, age, sex and designation. Figure

3153 shows the influence of different variables on the probability to getting or not COVID-

316 19. The probability (Odds Ratio) in relation at all variables was that becoming ill with

317 COVID-19 was maintained significantly lower in people treated with IVER/IOTAC

318 relative to non-treated people, Odds Ratio $0.11,95 \% 0.03$ to $0.33 ; p$-Value $=1.10^{-4}$. We

319 find that the mean value, including the Confidence Interval $(\mathrm{CI})$, was $<1$. This value

320 indicates that the protective effect of the IVER/IOTACRC in relation to the relative 
medRxiv preprint doi: https://doi.org/10.1101/2021.03.26.21254398; this version posted March 30, 2021. The copyright holder for this preprint (which was not certified by peer review) is the author/funder, who has granted medRxiv a license to display the preprint in perpetuity.

It is made available under a CC-BY-NC-ND 4.0 International license .

321 reduction of the risk to contracting COVID-19 were maintained even in interaction with

322 other variables.

323

324

$<$ Table $3>$

325

Table 3. Influence of different variables on the probability to getting or not COVID-19.

326

327

On the other hand, the probability of contracting COVID-19 was dependent on

the patient's preexisting comorbidity. People with comorbidities had a greater chance to

contracting COVID-19, Odds Ratio 5.58, 95\% 2.20 to $14.16, p$-Value $=1.10^{-5}$ (Odds

$330 \quad$ Ratio >1).

Regarding to age, this was study as continues variable, it can be observed that as

this increase, they had minor chance of getting COVID-19. This indicates that as age

333 increases by one unit, the chance of getting or contracting COVID-19 decreases $7 \%$ the

334 chance of getting COVID-19. This is because the Regression Coefficient (RC) has a

335 negative sign $(\mathrm{RC}=-2.37,95 \%-0.12$ to $-0.01, p$-Value $=0.018)$. This may be due to the

336 fact that the average age of all people enrolled in this study was 39 years, no

337 significative differences in booth EG and CG groups (Table 1), range between 32 to 41

338 year was $48.3 \%$. Odds Ratio to this variable was $0.93,95 \% 0.88$ to $0.98, p$-Value $=$

3390.02.

340 Getting COVID-19 was independent of sex when this variable was analyzed in

341 both groups (CG and EG) (Table 3). When this variable was studied using a stratified

342 model in male and female (see Table 1), we founded that the protective power of

343 ivermectin is conserved in both sex groups (Sex F Odds Ratio 0.148, 95\% 0.02 to 0.55

$344 p$-Value $=0.0012$ Sex M Odds Ratio $0.098,95 \% 0.002$ to $0.796 ; p$-Value $=0.010$ )

345 When the variable was studied using a stratified model in four age interquartile 
medRxiv preprint doi: https://doi.org/10.1101/2021.03.26.21254398; this version posted March 30, 2021. The copyright holder for this preprint (which was not certified by peer review) is the author/funder, who has granted medRxiv a license to display the preprint in perpetuity.

It is made available under a CC-BY-NC-ND 4.0 International license .

346 (see Table 1), we founded the protective power of ivermectin is conserved in the first

347 three age interquartiles. In people older 45 years of age we found the preventive 348 treatment wasn't effective.

349 In relation to designation (Healthcare vs. no-Healthcare) and comorbidities

350 getting COVID-19 was independent of this variable (see Table 3).

\section{Discussion}

352 Health personal is one of the most exposed groups to COVID-19 contagion, because of

353 their steady contact with infected patients. In our work we found a protective effect of

354 the intensive IVER/IOTACRC treatment in pre-exposure prophylaxis to COVID-19 in

355 health agents. The number of people affected by the disease was significantly higher in

356 the CG when compared to the EG who followed the intervention. In agreement with our

357 findings, Tarek Alacom et al. in an observational prophylactic study conducted in 118

358 healthcare workers, they found that significant minor contagious in subjects which re-

359 ceived ivermectin ${ }^{26}$. In the aforementioned study, a lower dose of ivermectin was used

360 unlike the treatment proposed here, held for one month and iota carrageenan was used

361 in conjunction with ivermectin. The findings in our work, in agreement with Carvallo $\mathrm{H}$

362 et al., confirm the hypothesis that the association IVER/IOTACRC works by decreasing

363 the possibility of infection with SARS-CoV-2 and possibly acts synergistically ${ }^{27}$. We

364 interpret that a double viral barrier would be formed that would enhance its action and

365 allow to increase the protective effect in the following way: i) The first barrier for viral

366 protection would be at the entry of the virus into the nasal cavity where the carrageenan

367 would behave as a mucolytic agent in the barrier of sulfacted polysaccharides with neg-

368 ative charge $\mathrm{e}^{28}$; ii) The other action of ivermectin is to decrease the viral load based on

369 its systemic cellular action ${ }^{29}$. It is coincident with reports of viral clearance in other clin- 
medRxiv preprint doi: https://doi.org/10.1101/2021.03.26.21254398; this version posted March 30, 2021. The copyright holder for this preprint (which was not certified by peer review) is the author/funder, who has granted medRxiv a license to display the preprint in perpetuity.

It is made available under a CC-BY-NC-ND 4.0 International license .

370 ical trials which evaluate the use of ivermectin to treat COVID-19. Ahmed S. et al.

371 found that a 5-day course of ivermectin resulted in earlier clearance of the virus com-

372 pared to placebo group ${ }^{30}$.

373 It is understood that it is capable of preventing the entry into the cell nucleus of the viral

374 RNA by blocking importin alpha/beta, thereby preventing replication since SARs-

375 COVID-2 does not have the nuclear mechanisms and enzymatic actions for the tran-

376 scription of new viral replicates ${ }^{31}$. In this direction, our work meets the work of Sharun

377 et al $(2020)^{32}$, who demonstrated the effect of ivermectin as a drug for inhibiting virus

378 replication in vitro laboratory conditions and places the drug as a new therapeutic can-

379 didate against SARS-CoV-2 / COVID-19. There are other works, either in prevention,

380 that found that a two-dose of ivermectin was associated with a reduction of SARS-CoV-

3812 infection, what makes ivermectin useful for healthcare personal preventive use ${ }^{33}$.

382 Secondary outcome found was that IVER/IOTACRC not only prevents the infections

383 rate, but also has a protective effect on reduction in symptoms number's presence, and

384 protection against the appearance of severe stages for COVID-19 disease (Figure 2). As

385 can be seen in Figure 2B, the EG only had mild cases, while the CG had mild, moderate

386 and severe cases, the differences between both groups being significant. We observed in

387 Table 2 that the symptoms description in the EG is significantly lower that CG. On the

388 other hand, it's necessary point out that the comorbidities or risk factor such as hyper-

389 tension, DBT, obesity or over 60 years old were similar in booth group (Table 1). So,

390 the results above mentioned, cannot attributed to presence to comorbidities in the CG.

391 In our greatest consideration, this would be an important contribution. When the effec-

392 tiveness of IVER / IOTACRC treatment was analyzed together with the other variables,

393 we found that, even in the presence of the comorbidity variable, the protective effect of

394 IVER / IOTACRC was maintained, with Odds Ratio <1 (Table 3). It is observed that the 
medRxiv preprint doi: https://doi.org/10.1101/2021.03.26.21254398; this version posted March 30, 2021. The copyright holder for this preprint (which was not certified by peer review) is the author/funder, who has granted medRxiv a license to display the preprint in perpetuity.

It is made available under a CC-BY-NC-ND 4.0 International license .

395 protective effect only has a small and no significant increased (87\% to $89 \%$ ) in the

396 chance getting COVID-19 in EG.

397 In relation to comorbidities and their greater impact on the severity of COVID-19, other

398 researchers have shown a positive relationship ${ }^{34,35}$. In relation to the sex variable, in

399 total group, we found that was independent in relation to treatment with

400 IVER/IOTACRC (Table 3). Stratified model by age showed that treatment was

401 protective for people under 45 years old, independent of sex.

402 The proposed prophylactic treatment is also independent of the designation (healthcare 403 and no healthcare).

404 During the study, there was no lack of adherence to IVER/IOTACRC treatment. We

405 hypothesized that good adherence was due to the design of the protocol, since it provid-

406 ed for the follow-up of the enrolled subjects periodically. These were designed every

407 seven days using two strategies: i) face-to-face visits, and ii) remote monitoring via tel-

408 emedicine. Another fact that may have influenced good adherence is that a short-term

409 intensive protocol was used.

410 Adverse effects

411 Regarding adverse effects, they were not reported in any case. The explanation for this

412 is that it could be due to the fact that IVER/IOTACRC only produces these effects when

413 the drug acts as an anti parasitic, unlike the viricidal action proposed in this study. An-

414 other fact that reinforces the absence of adverse effects is that the doses used in this pro-

415 tocol are low doses, in which previously, in the literature, it has been reported that they

416 do not produce adverse effects ${ }^{37}$.

417 Benefits

418 Through this study, it was possible to show a prophylactic effect of IVER/IOTACRC

419 against COVID-19 disease. This association of drugs was inexpensive and is also 
medRxiv preprint doi: https://doi.org/10.1101/2021.03.26.21254398; this version posted March 30, 2021. The copyright holder for this preprint (which was not certified by peer review) is the author/funder, who has granted medRxiv a license to display the preprint in perpetuity.

It is made available under a CC-BY-NC-ND 4.0 International license .

420 accessible in the local pharmaceutical industry (Argentina). It is more relevant

421 considering the limitations in vaccines supplies.

\section{$422 \quad$ Limitations}

423 The main limitation of this study was the number of agents to enroll. This trial does not

424 include the report of adverse event in the long run, so will be interesting to include in

425 future trials biochemical examination for control of potential adverse effects. Financial

426 limitations impacted in the study design, which not involved blinded evaluation and/or

427 placebo administration. It's also for considering the limitations of RT-PCR test in

428 relation to diagnosis, which in future works can be complimented with other approved

429 qualitative tests. On this last point, economic constraints had a determining rol.

$430 \quad$ Future work

431 We consider that our results, taking together with other trials, are encouraging for 432 develop further studies. New clinical intervention studies in our region and also partners

433 in other countries that may show the effect of the IVER/IOTACRC compound in mild-

434 stage outpatients. The design that would be proposed would be to use the same 435 treatment time but at higher doses. Other way, more strong results could be obtained 436 from randomized double blinded studies with long term controls to arrive to solid 437 conclusions about safety and efficacy of IVER/IOTACRC

\section{Conclusion}

439 The intensive preventive treatment (short-term) with IVER/IOTACRC was able 440 to reduce the health workers number infected with COVID-19. This treatment had an 441 additional effect in preventing the severity of the disease, since most of the patients who 442 received the treatment were mild.

443 In the presence of the comorbidity variable, the protective effect of IVER / 
444 IOTACRC was maintained in the chance getting COVID-19 in the treatment group.

445 The proposed prophylactic treatment is independent of the sex variable, and 446 designation (healthcare and no healthcare).

447 We propose a new therapeutic alternative for prevention and short-term 448 intervention scheme (intensive), which is of benefit of the health worker in this 449 pandemic accelerated time. This intervention did not produce lack of adherence to 450 treatment or adverse effects.

\section{Authors' contributions}

452 ESO supervised the database. ESO and DGG contributed with the data processing and 453 contributed to the statistical analysis. ESO, DGG and MPB were responsible for writing 454 the manuscript. MFM, FB, AG, CM and SPB contributed to data collection. REC and 455 LMR were the institutional managers to carry out the work. MPB supervised the 456 project.

\section{Transparency Declaration}

The authors not receive any monetary compensation for this work. They declare

460 that they have no known competing financial interests or personal relationships that 461 could have appeared to influence the work reported in this paper.

\section{Acknowledgements}

464 All the authors are grateful for the collaboration of the health and administrative 465 personnel of the "Angel C. Padilla" Clinical Hospital, "Nicolás Avellaneda" Hospital, 466 and the Emergency Department 107, and particularly, to Dr. Rogelio Calli contribution, 
medRxiv preprint doi: https://doi.org/10.1101/2021.03.26.21254398; this version posted March 30, 2021. The copyright holder for this preprint (which was not certified by peer review) is the author/funder, who has granted medRxiv a license to display the preprint in perpetuity. It is made available under a CC-BY-NC-ND 4.0 International license.

467 Director of Epidemiology of the Tucumán Province, Argentina. The authors thank Dr.

468 Augusto Bellomio (INSIBIO CONICET-UNT) for critical reading of the manuscript.

469

470

471 
medRxiv preprint doi: https://doi.org/10.1101/2021.03.26.21254398; this version posted March 30, 2021. The copyright holder for this preprint (which was not certified by peer review) is the author/funder, who has granted medRxiv a license to display the preprint in perpetuity.

It is made available under a CC-BY-NC-ND 4.0 International license .

\section{References}

473 1. WHO report 2020. WHO issues consensus document on the epidemiology of $474 \quad$ SARS.

475 2. Wang W, Xu Y, Gao R, et al. Detection of SARS-CoV-2 in Different Types of 476 Clinical Specimens. JAMA. March 2020. doi:10.1001/jama.2020.3786

477 3. Wu Z, McGoogan JM. Characteristics of and Important Lessons From the 478 Coronavirus Disease 2019 (COVID-19) Outbreak in China. JAMA. 2020;323(13):1239. doi:10.1001/jama.2020.2648

480 4. González Canga A, Sahagún Prieto AM, Diez Liébana MJ, Fernández Martínez N, Sierra Vega M, García Vieitez JJ. The Pharmacokinetics and Interactions of Ivermectin in Humans-A Mini-review. AAPS J. 2008;10(1):42-46. doi:10.1208/s12248-007-9000-9

5. Chong CR, Sullivan DJ. New uses for old drugs. Nature. 2007;448(7154):645646. doi:10.1038/448645a

6. Liu Z, Fang H, Reagan K, et al. In silico drug repositioning-what we need to know. Drug Discov Today. 2013;18(3-4):110-115. doi:10.1016/j.drudis.2012.08.005

7. Ashburn TT, Thor KB. Drug repositioning: identifying and developing new uses for existing drugs. Nat Rev Drug Discov. 2004;3(8):673-683. doi:10.1038/nrd1468

492 8. Götz V, Magar L, Dornfeld D, et al. Influenza A viruses escape from MxA

493 restriction at the expense of efficient nuclear vRNP import. Sci Rep.

$494 \quad$ 2016;6(1):23138. doi:10.1038/srep23138

495 9. Wagstaff KM, Rawlinson SM, Hearps AC, Jans DA. An AlphaScreen ${ }^{\circledR}$-Based 
medRxiv preprint doi: https://doi.org/10.1101/2021.03.26.21254398; this version posted March 30, 2021. The copyright holder for this preprint (which was not certified by peer review) is the author/funder, who has granted medRxiv a license to display the preprint in perpetuity.

It is made available under a CC-BY-NC-ND 4.0 International license .

J Biomol Screen. 2011;16(2):192-200. doi:10.1177/1087057110390360

10. Lundberg L, Pinkham C, Baer A, et al. Nuclear import and export inhibitors alter capsid protein distribution in mammalian cells and reduce Venezuelan Equine Encephalitis Virus replication. Antiviral Res. 2013;100(3):662-672. doi:10.1016/j.antiviral.2013.10.004

11. Tay MYF, Fraser JE, Chan WKK, et al. Nuclear localization of dengue virus (DENV) 1-4 non-structural protein 5; protection against all 4 DENV serotypes by the inhibitor Ivermectin. Antiviral Res. 2013;99(3):301-306. doi:10.1016/j.antiviral.2013.06.002

12. Caly L, Druce JD, Catton MG, Jans DA, Wagsta KM. The FDA-approved drug ivermectin inhibits the replication of SARS-CoV-2 in vitro. Antiviral Res. 2020;178(January):104787.

13. Padhy BM, Mohanty RR, Das S, Meher BR. Therapeutic potential of ivermectin as add on treatment in COVID 19: A systematic review and meta-analysis. $J$ Pharm Pharm Sci. 2020;23:462-469. doi:10.18433/jpps31457

14. Cassará FP. Ivermectina asociada a iota-Carragenina aplicada localmente en la cavidad bucal, en la profilaxis de la enfermedad COVID-19 en el personal de salud . Estudio IVERCAR01. 2020:1-23.

15. Hill A, Abdulamir A, Ahmed S, et al. $<\mathrm{p}>$ Meta-analysis of randomized trials of ivermectin to treat SARS-CoV-2 infection</p>. 2021:1-37.

16. Pacheco-Quito E-M, Ruiz-Caro R, Veiga M-D. Carrageenan: Drug Delivery Systems and Other Biomedical Applications. Mar Drugs. 2020;18(11):583. doi:10.3390/md18110583

17. Andersen KG, Rambaut A, Lipkin WI, Holmes EC, Garry RF. The proximal origin of SARS-CoV-2. Nat Med. 2020;26(4):450-452. doi:10.1038/s41591-020- 
medRxiv preprint doi: https://doi.org/10.1101/2021.03.26.21254398; this version posted March 30, 2021. The copyright holder for this preprint (which was not certified by peer review) is the author/funder, who has granted medRxiv a license to display the preprint in perpetuity.

It is made available under a CC-BY-NC-ND 4.0 International license .

$0820-9$

523 18. Recalcati S. Cutaneous manifestations in COVID $\square$ 19: a first perspective. $J$ Eur Acad Dermatology Venereol. 2020;34(5). doi:10.1111/jdv.16387

19. Mehta P, McAuley DF, Brown M, Sanchez E, Tattersall RS, Manson JJ. COVID19: consider cytokine storm syndromes and immunosuppression. Lancet. 2020;395(10229):1033-1034. doi:10.1016/S0140-6736(20)30628-0

20. Chen G, Wu D, Guo W, et al. Clinical and immunological features of severe and moderate coronavirus disease 2019. J Clin Invest. 2020;130(5):2620-2629. doi:10.1172/JCI137244

531 21. Glueck DH. Sample Size Calculations in Clinical Research 2nd edition by

CHOW, S.-C., SHAO, J., and WANG, H. Biometrics. 2008;64(4):1307-1308.

doi:10.1111/j.1541-0420.2008.01138_10.x

534 22. World Health Organization. Clinical Spectrum of SARS-CoV-2 Infection.

535 https://www.covid19treatmentguidelines.nih.gov/overview/clinical-spectrum/.

$536 \quad$ Published 2020.

537 23. WHO-adverse reaction terminology (WHO-ART). In: Dictionary of

$538 \quad$ Pharmaceutical Medicine. Vienna: Springer Vienna; 2009:192-193.

539 doi:10.1007/978-3-211-89836-9_1467

540 24. Osterberg L, Blaschke T. Adherence to Medication. $N$ Engl J Med.

$541 \quad$ 2005;353(5):487-497. doi:10.1056/NEJMra050100

542 25. Puigdemont N, Valverde I. Methods to assess medication adherence. Ars Pharm.

543 2018;59(3):163-172. \%0Ascielo.isciii.es/pdf/ars/v59n3/2340-9894-ars-59-03-

544 163.pdf\%0A\%0A.

545 26. Alam MT, Murshed R, Gomes PF, et al. Ivermectin as Pre-exposure Prophylaxis 546 for COVID-19 among Healthcare Providers in a Selected Tertiary Hospital in 
medRxiv preprint doi: https://doi.org/10.1101/2021.03.26.21254398; this version posted March 30, 2021. The copyright holder for this preprint (which was not certified by peer review) is the author/funder, who has granted medRxiv a license to display the preprint in perpetuity.

It is made available under a CC-BY-NC-ND 4.0 International license .

547 Dhaka - An Observational Study. Eur J Med Heal Sci. 2020;2(6).

$548 \quad$ doi:10.24018/ejmed.2020.2.6.599

549 27. Hector E C. Covid 19 and Ivermectin Prevention and Treatment Update. J Infect

$550 \quad$ Dis Travel Med. 2020;4(S1). doi:10.23880/jidtm-16000s1-007

551 28. Héctor C, Roberto H, Psaltis A, Veronica C. Study of the Efficacy and Safety of

552 Topical Ivermectin + Iota-Carrageenan in the Prophylaxis against COVID-19 in

553 Health Personnel. J Biomed Res Clin Investig. 2020;2(1). doi:10.31546/2633-

$554 \quad 8653.1007$

555 29. Krolewiecki A, Lifschitz A, Moragas M, et al. Ivermectin as Pre-exposure

556 Prophylaxis for COVID-19 among Healthcare Providers in a Selected Tertiary

557 Hospital in Dhaka - An Observational Study. Eur J Med Heal Sci. 2020;2(6):1-

558 22. doi:10.24018/ejmed.2020.2.6.599

559 30. Ahmed S, Karim MM, Ross AG, et al. A five-day course of ivermectin for the

560 treatment of COVID-19 may reduce the duration of illness. Int J Infect Dis.

$561 \quad 2021 ; 103: 214-216$.

562 31. Caly L, Druce JD, Catton MG, Jans DA, Wagstaff KM. The FDA-approved drug

563 ivermectin inhibits the replication of SARS-CoV-2 in vitro. Antiviral Res.

$564 \quad$ 2020;178:104787. doi:10.1016/j.antiviral.2020.104787

565 32. Sharun K, Dhama K, Patel SK, et al. Ivermectin, a new candidate therapeutic

566 against SARS-CoV-2/COVID-19. Ann Clin Microbiol Antimicrob. 2020;19(1):1-

$567 \quad$ 5. doi:10.1186/s12941-020-00368-w

568 33. Chang GA, Figueredo ANT. COVID-19: IVERMECTIN PROPHYLAXIS IN

569 ADULT CONTACTS. Report on Health Personnel and Post-Exposure

$570 \quad$ Prophylaxis. Preprint. Res Gate. 2020;(October).

$571 \quad$ doi:10.13140/RG.2.2.11985.35680/3 
medRxiv preprint doi: https://doi.org/10.1101/2021.03.26.21254398; this version posted March 30, 2021. The copyright holder for this preprint (which was not certified by peer review) is the author/funder, who has granted medRxiv a license to display the preprint in perpetuity. It is made available under a CC-BY-NC-ND 4.0 International license.

572 34. Wang T, Du Z, Zhu F, et al. Comorbidities and multi-organ injuries in the treatment of COVID-19. Lancet. 2020;395(10228):e52. doi:10.1016/S0140$6736(20) 30558-4$

575 35. Renu K, Prasanna PL, Valsala Gopalakrishnan A. Coronaviruses pathogenesis, 576 comorbidities and multi-organ damage - A review. Life Sci. 2020;255:117839. doi:10.1016/j.lfs.2020.117839 
medRxiv preprint doi: https://doi.org/10.1101/2021.03.26.21254398; this version posted March 30, 2021. The copyright holder for this preprint (which was not certified by peer review) is the author/funder, who has granted medRxiv a license to display the preprint in perpetuity. It is made available under a CC-BY-NC-ND 4.0 International license .

Figure 1. CONSORT Flow Diagram

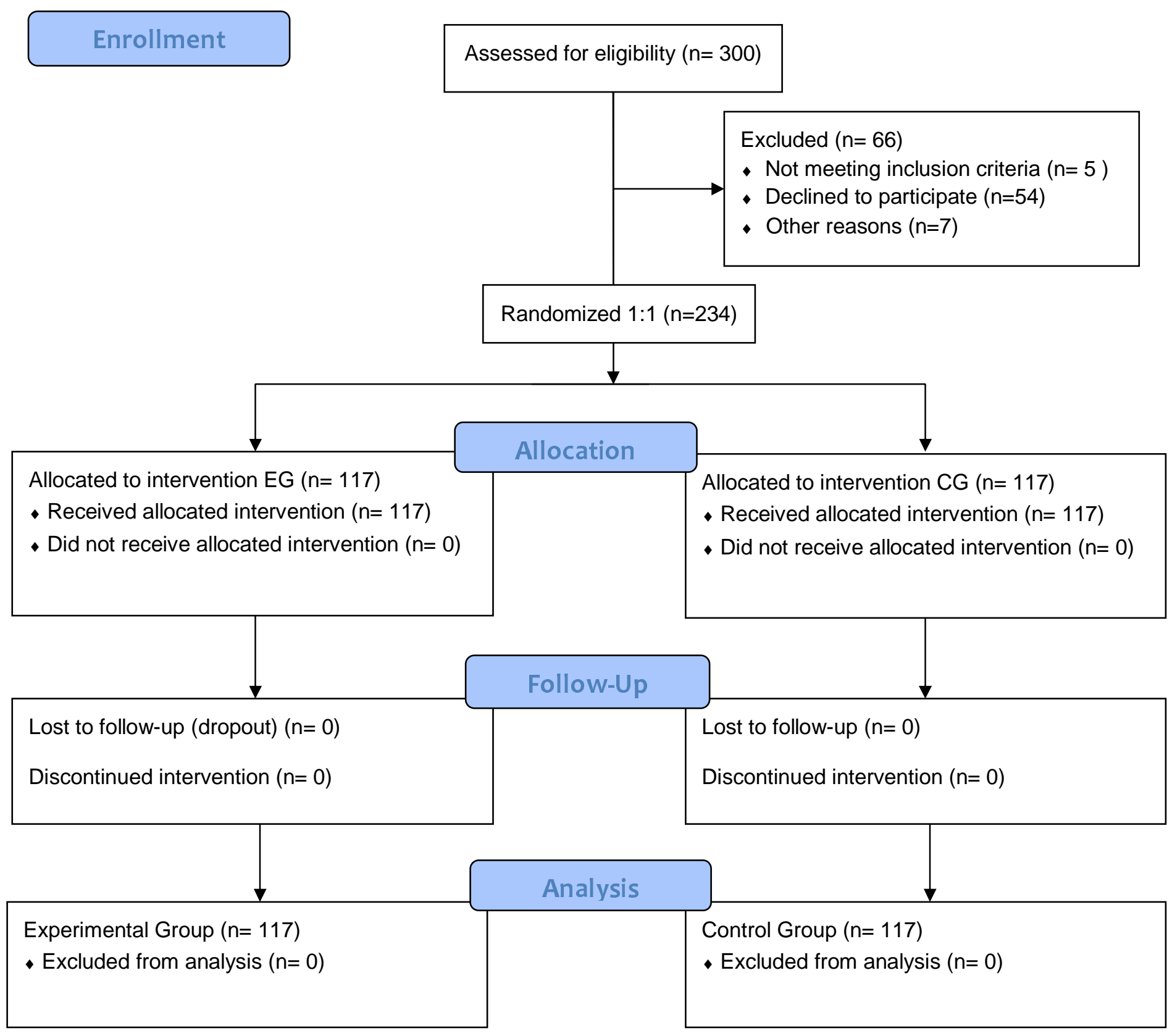


Figure 2

Figure 2. COVID-19 case in EG vs CG. A) Number of COVID-19 and healthy cases in Experimental and Control Group (n=234). B) Clinical state of the COVID-19 cases in Experimental and Control Group ( $\mathrm{n}=234)$.

\section{(A)}

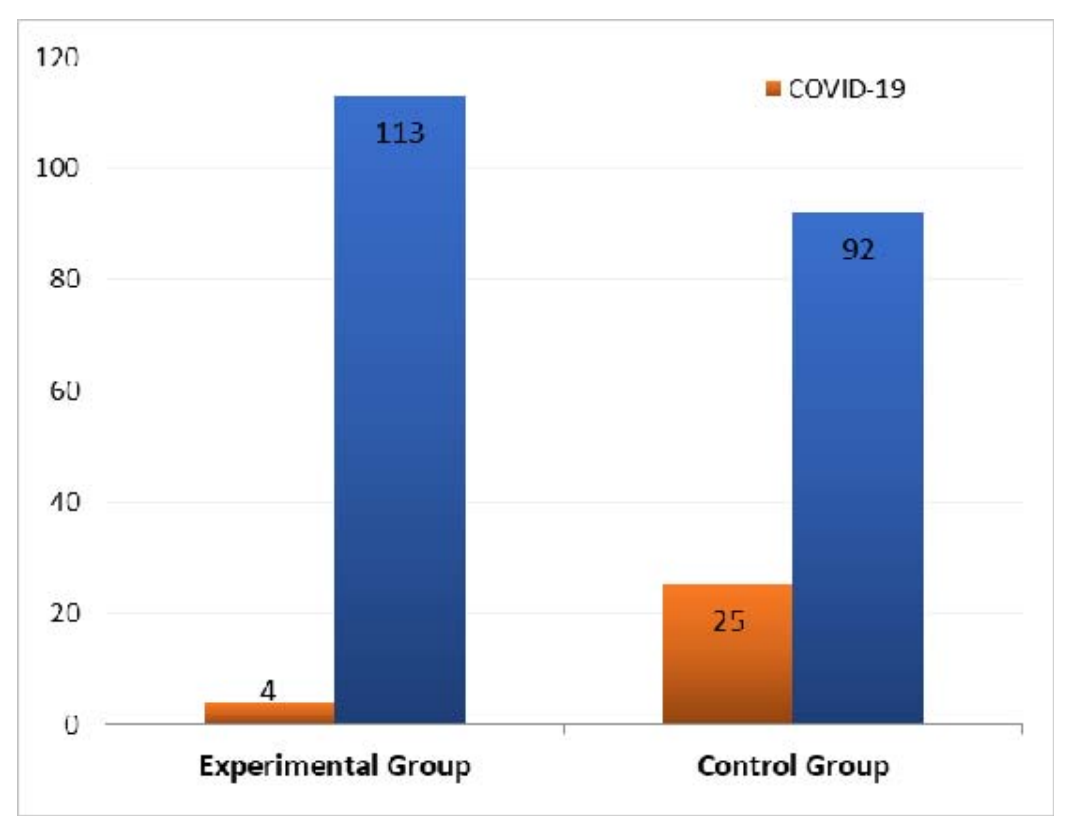

(B)

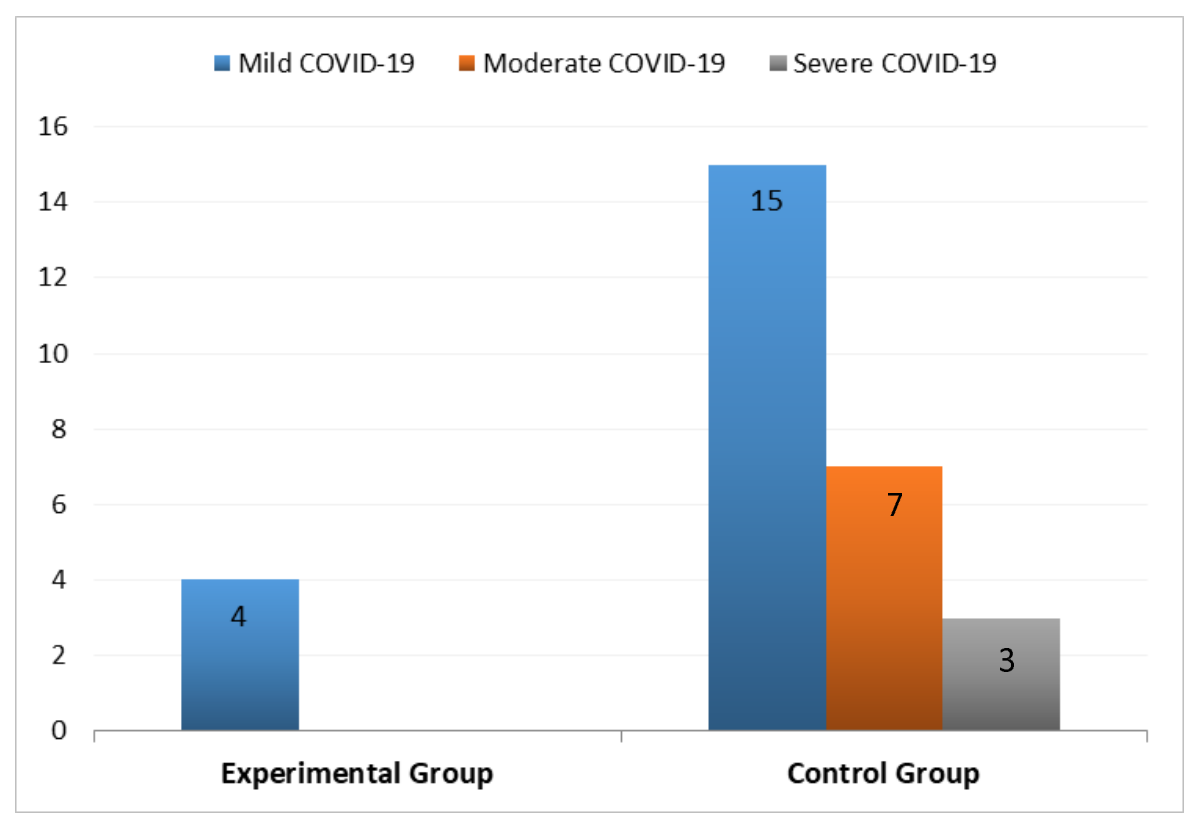


Table 1. Demographic Profile

\begin{tabular}{|c|c|c|}
\hline Variables & $\begin{array}{c}\text { Experimental Group } \\
(n=117)\end{array}$ & $\begin{array}{c}\text { Control Group } \\
(\mathrm{n}=117)\end{array}$ \\
\hline \multicolumn{3}{|l|}{ Demographic profile } \\
\hline Median Age (in years) & 40 & 37 \\
\hline Interquartile Range (IQR) & {$\left[\mathrm{IQR}_{25}: 32 ; \mathrm{IQR}_{75}: 46\right]$} & {$\left[\mathrm{IQR}_{25}: 33 ; \mathrm{IQR}_{75}: 44\right]$} \\
\hline \multicolumn{3}{|l|}{ Gender - $\mathbf{n}^{\circ} .(\%)$} \\
\hline Female & $65(55.56 \%)$ & $69(58.97 \%)$ \\
\hline Male & $52(44.44 \%)$ & $48(41.03 \%)$ \\
\hline \multicolumn{3}{|l|}{ Co-morbidities - $\mathbf{n}^{\circ} .(\%)$} \\
\hline HTA & $13(11.11 \%)$ & $8(7.55 \%)$ \\
\hline DBT & $10(8.55 \%)$ & $7(6.60 \%)$ \\
\hline Obesity & $10(8.55 \%)$ & $18(16.98 \%)$ \\
\hline$>60$ years & $5(4.27 \%)$ & $5(4.27 \%)$ \\
\hline Renal & $3(1.36 \%)$ & $2(1.89 \%)$ \\
\hline \multicolumn{3}{|l|}{ Designation } \\
\hline Healthcare & $99(84.62 \%)$ & $82(70.09 \%)$ \\
\hline No Healthcare & $18(15.38 \%)$ & $35(29.91 \%)$ \\
\hline
\end{tabular}

HTA: Hypertension; DBT: Diabetes; Chronic Kidney Disease. 
medRxiv preprint doi: https://doi.org/10.1101/2021.03.26.21254398; this version posted March 30, 2021. The copyright holder for this preprint (which was not certified by peer review) is the author/funder, who has granted medRxiv a license to display the preprint in perpetuity.

\section{It is made available under a CC-BY-NC-ND 4.0 International license .}

Table 2. Clinical Profile

\begin{tabular}{lccc} 
Variables & $\begin{array}{c}\text { Experimental } \\
\text { Group } \\
(\mathbf{n}=\mathbf{1 1 7})\end{array}$ & $\begin{array}{c}\text { Control } \\
\text { Group } \\
(\mathbf{n}=\mathbf{1 1 7})\end{array}$ & $\boldsymbol{p}$-Value \\
\hline Symptom - $\mathbf{n}^{\circ} \mathbf{.}(\boldsymbol{\%})$ & $1(0.85 \%)$ & $20(17.09 \%)$ & $1.10^{-5 *}$ \\
Fever $>38$ & $1(0.85 \%)$ & $8(6.84 \%)$ & $0.02^{*}$ \\
Diarrhea & 0 & $19(16.24 \%)$ & $1.10^{-5 *}$ \\
Taste and/or smell & 0 & $6(5.13 \%)$ & $0.01^{*}$ \\
disturbance & 0 & $9(7.69 \%)$ & $1.10^{-5 *}$ \\
Oxygen Saturation $\left(\mathrm{SpO}_{2}\right)$ & $1(0.85 \%)$ & $18(15.38 \%)$ & $1.10^{-5 *}$ \\
Polymyoarthralgia, & $1(0.85 \%)$ & $7(5.98 \%)$ & $0.03 *$ \\
Headache & 0 & $8(6.84 \%)$ & $1.10^{-5 *}$ \\
Body pain & 0 & $1(0.85 \%)$ & 0.32 \\
Abdominal pain & & & \\
ALRI symptoms and signs & & & \\
(*) p-Value $<0.05$. & & &
\end{tabular}


medRxiv preprint doi: https://doi.org/10.1101/2021.03.26.21254398; this version posted March 30, 2021. The copyright holder for this preprint (which was not certified by peer review) is the author/funder, who has granted medRxiv a license to display the preprint in perpetuity. It is made available under a CC-BY-NC-ND 4.0 International license.

Figure 3. Logistic regression model in patient with COVID -19 in both groups.

Variables

Ivermectin / Iota-Carrageenan

Comorbidity

Designation

Sex

Age (in years)
Odds Ratio

0.13

3.45

2.79

1.77

0.96
p-Value

0.000

$1.55-7.67$

0.002

$0.81-9.63$

0.103

$0.77-4.08$

0.178

$0.92-1.01$

0.142 